\title{
PERAN KOMISI PEMILIHAN UMUM (KPU) DALAM MENUMBUHKAN PARTISIPASI POLITIK BAGI PEMILIH PEMULA DI KECAMATAN PONTIANAK BARAT
}

\author{
Fety Novianty $^{1}$, Erna Octavia $^{2}$ \\ ${ }_{1,2}$ Program Studi Pendidikan Pancasila dan Kewarganegaraan \\ Fakultas Ilmu Pendidikan dan Pengetahuan Sosial IKIP PGRI Pontianak \\ Jalan Ampera Nomor 88 Pontianak - 78116, Telepon (0561) 748219 Fax. (0561) 589855 \\ ${ }^{1}$ Alamat email: putrikhanza96@yahoo.co.id
}

\begin{abstract}
Abstrak
Penelitian ini bertujuan untuk mendeskripsikan tentang (1) Gambaran umum tentang realitas partisipasi politik bagi pemilih pemula di Kecamatan Pontianak Barat; (2) Program kerja Komisi Pemilihan Umum (KPU) dalam menumbuhkan partisipasi politik bagi pemilih pemula di Kecamatan Pontianak Barat; (3) Hambatan yang dialami Komisi Pemilihan Umum (KPU) dalam menumbuhkan partisipasi politik bagi pemilih pemula di Kecamatan Pontianak Barat; (4) Upaya Komisi Pemilihan Umum (KPU) dalam mengatasi hambatan untuk menumbuhkan partisipasi politik bagi pemilih pemula di Kecamatan Pontianak Barat. Penelitian ini menggunakan pendekatan kualitatif dengan bentuk studi deskriptif. Teknik pengumpul data yang digunakan adalah teknik observasi langsung, teknik komunikasi langsung dan teknik studi dokumenter, dengan alat pengumpul datanya adalah pedoman observasi, pedoman wawancara dan dokumentasi.
\end{abstract}

Kata Kunci: Komisi Pemilihan Umum (KPU), Partisipasi Politik, Pemilih Pemula

\begin{abstract}
This research aims to describe (1) a general description of the reality of political participation for novice voters in Pontianak Barat District; (2) The General Election Commission work program in fostering political participation for novice voters in Pontianak Barat District; (3) Obstacles experienced by the General Election Commission in fostering political participation for novice voters in Pontianak Barat District; (4) Efforts of the General Election Commission to overcome barriers to foster political participation for novice voters in Pontianak Barat District. This research uses a qualitative approach with a descriptive study. Data collection techniques used are direct observation techniques, direct communication techniques and documentary study techniques, with data collection tools are observation guidelines, interview guidelines and documentation.
\end{abstract}

Keywords: General Election Commission, Political Participation, Beginner Voters

\section{PENDAHULUAN}

Salah satu bentuk partisipasi politik rakyat dalam pemerintahan yang demokratis adalah keikutsertaan anggota masyarakat dalam pemilihan umum. Dalam sistem politik semacam ini pemilihan umum tak dapat terlepas dari lembaga negara yang menjadi pondasi dalam penyelenggaraan pemilu yang disebut sebagai Komisi Pemilihan Umum, baik dalam tingkat provinsi maupun tingkat daerah. Penyelenggara pemilu berpedoman kepada asas mandiri, jujur, 
adil, kepastian hukum, tertib penyelenggara Pemilu, kepentingan umum, keterbukaan, profesionalitas, akuntabilitas, efisiensi dan efektivitas agar melahirkan pemilihan umum yang bersifat demokratis.

Mewujudkan negara yang demokratis adalah cita-cita besar bangsa Indonesia. Demokrasi adalah kedaulatan rakyat, berarti rakyatlah yang harus menjadi pusat grafitasi dari keseluruhan aktifitas politik yang berkaitan dengan pengaturan negara. Kemajuan praktek demokrasi disuatu negara ditandai dengan seberapa jauh rakyat dan aspirasi mereka menjadi perumusan kebijakan publik sekaligus referensi utama bagi setiap lembaga yang bertugas mecari kepentingan publik. Wujud dari proses demokrasi di Indonesia dapat dilihat secara nyata dalam proses pemilihan umum (pemilu). Partisipasi rakyat dalam pemilu adalah hal mutlak. Berhasil tidaknya pemilu sangat bergantung pada suara mayoritas rakyat, karena suara rakyat ini yang akan menentukan nasib bangsa kedepan. Indonesia telah mengalami pasang surut dalam sistem pemilu.

Memilih figur pemimpin negara ataupun daerah secara langsung merupakan momentum yang sangat krusial bagi suatu negara untuk itu harus dibarengi dengan tingginya tingkat partisipasi politik rakyat. Dalam hal ini partisipasi yang diinginkan bukan hanya sekedar menggunakan hak pilihnya tetapi yang terpenting bagaimana hak pilih tersebut dapat diimplementasikan dengan pilihan rasional dalam rangka memberikan yang terbaik untuk negara. Pelajar atau remaja adalah sebuah komunitas yang cukup besar dan cukup diperhitungkan sebagai basis suara pada setiap pemilu. Komunitas pelajar yang baru pertama kali mengikuti pemilihan umum disebut pemilih pemula atau pemilih yang baru pertama kali memilih karena usia mereka baru memasuki usia pemilih "Pemilih pemula adalah mereka yang telah berusia 17-22 tahun, yang telah memiliki hak suara dalam pemilu dan terdiri atas pelajar, mahasiswa ataupun pekerja muda yang belum berusia 17 tahun tetapi telah menikah"

Pemilih pemula usia Sekolah Menengah Atas (SMA) memang menjadi segmen yang unik, seringkali memunculkan kejutan dan tentu saja menjanjikan secara kuantitas. Disebut unik, sebab perilaku pemilih pemula dengan antusiasme yang tinggi sementara keputusan pilihan yang belum bulat. Sebenarnya pemilih 
pemula bisa ditempatkan sebagai swing voters yang sesungguhnya. Pilihan politik mereka belum dipengaruhi motivasi ideologis tertentu dan lebih didorong oleh konteks dinamika lingkungan politik lokal. Pemilih pemula mudah dipengaruhi kepentingan-kepentingan tertentu, terutama oleh orang terdekat seperti anggota keluarga, mulai dari orangtua hingga kerabat. Kondisi tersebut tampak jika merunut perilaku pemilih pemula pada beberapa penyelenggaraan pemilihan kepala daerah (pilkada).

Sosialisasi pemilu bagi pemilih pemula saat ini sangat penting mengingat perlu adannya transfer pengetahuan politik, tidak hanya yang terkait dengan berbagai hal tentang pemilu seperti sistemnya, tahapannya, dan lembaga penyelengaranya tetapi lebih dari itu terkait juga dengan arti penting pemilu bagi bangsa dan negara, untuk itu muatan dalam sosialisasi pemilu sebagai bagian dari pendidikan pemilih harus dapat mengembangkan kompetasi kewarganegaraan yang utuh. "Kompetensi kewarganegaraan adalah seperangkat pengetahuan, nilai dan sikap serta keterampilan yang mendukung menjadi warga negara yang partisipatif dan bertanggung jawab dalam kehidupan bermasyarakat dan bernegara" (Branson, 1999:8-9). Kompetensi ini nantinya akan memberi bekal kepada setiap pemilih pemula agar menjadi warganegara cerdas dan baik (be smart and good citizenship). Tiga kompetensi penting yang harus dimiliki oleh pemilih pemula adalah kompetensi kewarganegaraan yang diadopsi dari pendapat Branson (1999:8) yaitu:

1. Civic knowledge (pengetahuan kewarganegaraan), berkaitan dengan kandungan atau apa yang seharusnya diketahui oleh pemilih pemula

2. Civic skill (kecakapan kewarganegaraan), adalah kecakapan intelektual dan partisipatoris pemilih pemula yang relevan; dan

3. Civic disposition (watak kewarganegaraan) yang mengisyaratkan pada karakter publik maupun privat yang penting bagi pemeliharaan dan pengembangan demokrasi konstitusional.

Sosialisasi pemilu sebagai proses pembentukan dan pengembangan kompetensi kewarganegaraan saat ini merupakan suatu kebutuhan dasar bagi pemilih pemula. hal ini penting karena dengan kompetensi kewarganegaraan yang mapan pemilih pemula dapat mempertimbangkan sisi kualitas calon yang akan 
dipilih. Pembentukan dan pengembangan kompetensi kewarganegaraan dalam sosialisasi pemilu dan pendidikan pemilih, mengajak pemilih pemula tidak hanya tahu tentang bagaimana memilih, tetapi juga membangun kesadaran dan daya kritis terhadap setiap tahapan proses pemilu. Dengan begitu, pemilih pemula tidak lagi menjadi objek dalam pemilu, tetapi sebaliknya mereka bisa menjadi subjek yang kritis dalam menentukan pilihan politik, sekaligus menjadi pendorong pendewasaan partai politik untuk memperjuangkan aspirasi rakyat banyak, bukan kepentingan orang per-orang, sehingga hal ini mampu menumbuhkan demokrasi di Indonesia.

Masih Rendahnya partisipasi politik pemilih pemula disebabkan salah satu faktornya adalah sosialisai hanya dilakukan ketika menjelang Pemilukada. Selain itu, masih belum optimalnya program kerja Komisi Pemilihan Umum (KPU) dalam memberikan pemahaman dan kesadaran bagi pemilih pemula untuk ikut berpartisipasi dalam pemilukada, karena masih kurangnya Peran KPU melakukan sosialisasi tentang pemilu. Pemahaman akan pentingnya peran serta pemilih pemula dalam pemilu merupakan suatu keharusan untuk ditanamkan. Peran KPU seharusnya adalah menanamkan kesadaran dalam melaksanakan Pemilu sehingga bisa memberikan pedoman terhadap penetapan organisasi dan tata cara penyelenggaraan pemilihan wali kota dan wakil walikota Pontianak sesuia dengan tahapan yang diatur dalam ketentuan peraturan perundang-undangan.

Berangkat dari uraian diatas, maka penulis tertarik untuk melakukan penelitian yang lebih mendalam tentang "Peran Komisi Pemilihan Umum (KPU) Dalam Menumbuhkan Partisipasi Politik Bagi Pemilih Pemula Di Kecamatan Pontianak Barat". Dengan rumusan masalah sebagai berikut: (1) Bagaimanakah realitas partisipasi politik bagi pemilih pemula di Kecamatan Pontianak Barat; (2) Bagaimanakah program kerja Komisi Pemilihan Umum (KPU) Pontianak dalam menumbuhkan partisipasi politik bagi pemilih pemula di Kecamatan Pontianak Barat; (3) Apa sajakah hambatan Komisi Pemilihan Umum (KPU) dalam menumbuhkan partisipasi politik bagi pemilih pemula di Kecamatan Pontianak Barat; (4) Bagaimana upaya Komisi Pemilihan Umum (KPU) dalam mengatasi 
hambatan untuk menumbuhkan partisipasi politik bagi pemilih pemula di Kecamatan Pontianak Barat.

\section{METODE}

Metode penelitian yang digunkan disini adalah penelitian kualitatif, dengan tujuan mendapatkan gambaran secara jelas tentang bagimana "Peran Komisi Pemilihan Umum (KPU) Dalam Menumbuhkan Partisipasi Politik Bagi Pemilih Pemula di Kecamatan Pontianak Barat”. Bentuk penelitian yang digunakan dalam penelitian ini adalah bentuk penelitian deskriptif. Bentuk penelitian ini berusaha mendeskripsikan suatu gejala, atau fenomena dari peristiwa yang terjadi. Berdasarkan masalah penelitian diatas, peneliti menggunakan bentuk penelitian deskriptif. Hal ini disebabkan peneliti menganalisis tentang bagaimana Peran Komisi Pemilihan Umum (KPU) Dalam Menumbuhkan Partisipasi Politik Bagi Pemilih Pemula di Kecamatan Pontianak Barat. Adapun yang menjadi subjek dalam penelitian ini adalah Ketua KPU, Anggota KPU, Siswa, dan Mahasiswa. Teknik pengumpul data yang digunakan dalam penelitian ini adalah teknik observasi langsung, teknik komunikasi langsung, dan teknik studi dokumenter dengan alat pengumpul datanya adalah pedoman observasi, pedoman wawancara dan dokumentasi. Untuk teknik analisis data yang digunakan adalah teknik analisis data kualitatif dengan tahap pengumpulan data, reduksi data dan verifikasi data.

\section{HASIL PEMBAHASAN}

\section{Realitas Partisipasi Politik bagi Pemilih Pemula di Kecamatan Pontianak Barat}

Sebelum membahas lebih lanjut mengenai Realitas partisipasi politik bagi pemilih pemula di kecamatan Pontianak Barat. Partisipasi politik adalah kegiatan seorang atau sekelompok orang untuk ikut serta aktif dalam kegiatan politik yang bisa dilakukan dengan cara berpartisipasi langsung dalam memilih pemimpin maupun secara tidak langsung mempengaruhi kebijakan publik. Ramblan Surbakti memberikan definisi singkat mengenai partisipasi politik sebagai bentuk keikutsertaan warga Negara biasa dalam menentukan segala keutusan yang 
menyangkut atau mempengaruhi hidupnya (Surbakti, 1999: 140). Partisipasi politik dapat bersifat perorangan (individu) misalnya melakukan kritik dan memberi masukan terhadap kebijakan public baik dilakukan dengan cara menulis di media ataupun dilakukan secara langsung menyampaikan kritik dan saran kepada pengambil kebijakan. Selain itu partisipasi politik bersifat kelompok teroganisir (LSM, Parpol, ormas, maupun organisasi kepemudaan dan organisasi kemahasiswaan).

Jika dianalisis bentuk-bentuk partisipasi politik pemilih pemula pada PemilihanUmum Legislatif 2014 di Kecamatan Pontianak Barat menurut pendapat yangdikemukakan oleh Miriam Budiardjo (2008: 367) mengatakan bahwa partisipasi politik merupakan kegiatan seseorang atau sekelompok orang untuk ikut serta secara aktif dalam kehidupan politik, antara lain dengan jalan memilih pimpinan negara dan, secara langsung atau tidak langsung, memengaruhi kebijakan pemerintah. Kegiatan ini mencakup tindakan seperti memberikan suara dalam pemilihan umum, menghadiri rapat umum, mengadakan hubungan dengan pejabat pemerintah atau anggota parlemen, menjadi anggota partai atau salah satu gerakan sosial dan sebagainya.

Dalam UUD 1945 Bab I Pasal 1 ayat 2 kedaulatan berada di tangan rakyat dan dilakukan menurut Undang-Undang. Dalam demokrasi, yang menjalankan kedaulatan rakyat adalah wakil-wakil rakyat yang di pilih atau ditentukan sendiri oleh rakyat dan untuk menentukan siapakah yang berwenang untuk mewakili rakyat, maka diadakanlah pemilihan umum. Pemilih pemula yang sebelumnya hanya menjadi penonton proses politik pemilihan anggota legislatif, kini mereka telah menjadi bagian dari proses penentuan calon anggota legislatif yang secara tidak langsung nantinya akan juga membawa aspirasi dari pemilih pemula itu sendiri di parlemen.Pemilhan umum anggota legislatif ini juga merupakan sarana perwujudan partisipasi politik rakyat. Partisipasi politik itu sendiri dapat dijabarkan melalui aktivitas-aktivitas politik yang dilakukan oleh masyarakat seperti pemungutan suara untuk memilih wakilrakyat ataupun kepala negara, itu merupakan bentuk yang paling mudah kita kenali. Pemilu legislatif 2014 merupakan rangkaian pesta demokrasi rakyat Indonesiakarena dilanjutkan dengan 
pemilihan umum Presiden dan Wakil Presiden. Oleh karena itu tidak heranjika masyarakat di Kecamatan Pontianak Barat begitu antusias menyukseskan pesta demokrasi tersebut khususnya dari kalangan pemilih pemula. Hal tersebut dapat dilihat dari hasil wawancara dengan informan-informan yangmenunjukan semua informan yang diwawancarai oleh peneliti menggunakan hakpilihnya pada Pemilu legislatif 2014 ini. Mereka melakukanya dengan berbagai alasan,antara lain karena kesadaran politik sebagai warga negara yang baik danada jugakarena Pemilu legislatif 2014 ini merupakan pemilu pertama bagi mereka.

\section{Program Kerja Komisi Pemilihan Umum (KPU) dalam menumbuhkan partisipasi politik bagi pemilih pemula di Kecamatan Pontianak Barat}

Secara umum, kinerja KPU kota pontianak kecamatan pontianak barat terkait sosialisasi yang dilakukanselama pemilu tahun 2014 sudah berjalan dengan cukup baik. Dari pernyataan diatas Sujadi, S.Ag sebagai ketua KPU juga mengatakan bahwa'Program yang dilaksanakan sesuai yang dianggarkan oleh KPU bentuknya sosialisasi tatap muka bisa dalam bentuk-bentuk perlombaan bisa juga bentuk penyampaian pamphlet, poster spanduk siaran radio televisi sesuai dengan kemampuan kita, segmen yang dijangkau seluruh segnmen masyarakat minimal, pertama pemilih pemula, kedua pemilihan kaum agamawan, ketiga kelompok pemilih wanita, disabilitas".

Pada beberapa kegiatan sosialisasi yang dilaksanakan langsung oleh KPU kota Pontianak yang diantaranya adalah sosialisasi pada kalangan SMA sederajat sebagai pengenalan kepada pemilih pemula akan pentingnya ikut terlibat dalam pemilu, atau dengan mengunjungi beberapa elemen masyarakat yang memang membutuhkan penyuluhan akan kesadaran berpolitik dan berdemokrasi atauterhadap masyarakat yang memang belum paham mengenai politik. Oleh karenaKomisi Pemilihan Umum (KPU) kota pontianak kecamatan Pontianak barat sebenarnya lebihbanyak berfungsi sebagai koordinator, sehingga tidak terlalu banyak kegiatan dan aktivitas yang dilakukan berbentuk program kegiatan kepada masyarakat.

Hambatan Komisi Pemilihan Umum (KPU) dalam menumbuhkan partisipasi politik bagi pemilih pemula di kecamatan Pontianak Barat 
Kesadaran politik warga negara menjadi faktor determinan dalam partisipasi politik masyarakat, artinya sebagai hal yang berhubungan pengetahuan dan kesadaran akan hak dan kewajiban yang berkaitan dengan lingkungan masyarakat dan kegiatan politik menjadi ukuran dan kadar seseorang terlibat dalam proses partisipasi politik. Begitu juga dengan pemilih pemula yang baru mamasuki usia hak pilih sebagian besar belum memiliki jangkauan politik yang luas untuk menentukan kemana mereka harus memilih.

Secara umum berkaitan dengan sumber daya manusia (SDA) untuk mengurangi hambatan itu diadakan rapat rutin mingguan kaitannya adalah untuk memberikan pemahaman terhadap penyelenggaraan pemilihan, baik komisioner maupun stap pemilihan sehingga diperoleh bentuk-bentuk koordinasi yang sama pemahaman, yang sama informasi sehingga tidak terjadi miss komunikasi diinternal KPU. Apa saja yang diharuskan kepada stap kemudian bagaimana kita komisioner mengawasi dan kemudian kita adakan evaluasi satu bulan sekali sehingga kita tahu bagian-bagianmana saja yang harus kita perbaiki. Yang namanya hambatan itu pasti ada dan tidak ada satu lembagapun yang tidak mempunyai hambatan hanya tingkat keseriusannya yang berbeda-beda dan bagaimana cara menanganinya itu yang terpenting. Jadi penanganankita adalah pendekatan, kemudian pertemuan rapat yang sifatnya individu antara komisioner dan kasubak yang kaitannya tugas masing-masing.

\section{Upaya Komisi Pemilihan Umum (KPU) dalam mengatasi hambatan untuk menumbuhkan partisipasi politik di kecamatan Pontianak Barat}

Upaya Komisi Pemilihan Umum dalam meningkatkan partisipasi masyarakat dalam dalam pemilu legislatif melalui sosialisasi memberikan pendidikan pemilih (vote education), tata cara dan Peran masyarakat dalam Pemilu, pemahaman mengenai demokrasi dan pentingnya partisipasi masyarakat, meningkatkan partisipasi masyarakat dalam Pemilu yang berkualitas. Peran masyarakat dalam Pemilu (Pileg, Pilpres, Pemilukada) merupakan faktor yang sangat penting, karena salah satu indikator keberhasilan Pemilu adalah tingkat partisipasi masyarakat dalam menggunakan hak pilihnya. Pemilu merupakan mekanisme politik penting yang menandai implementasi kedaulatan rakyat. 
Negara yang berkedaulatan rakyat akan menggelar Pemilu sesuai ketentuan yang berlaku untuk melembagakan dan membumikan demokrasi. Pemilu digelar dengan mekanisme dan sistem yang menjamin adanya keadilan, kesamaan hak, transparansi,berkesinambungan dan akuntabilitas.

Oleh karena itu, rakyat menjadi tertarik berpartisipasi dalam Pemilu. Negara yang seperti ini merupakan negara yang dikategorikan sebagai negara yang tingkat demokrasinya baik, namun sebaliknya apabila suatu negara tidak melaksanakan Pemilu atau tidak mampu melaksanakan Pemilu dengan baik, yaitu terjadi berbagai manipulasi, kecurangan, permainan kotor dan diskriminasi, maka negara itu dinilai sebagai negara yang anti demokrasi atau tingkat demokrasinya berkategori rendah.

\section{SIMPULAN}

Berdasarkan pembahasan dan analisis yang telah dipaparkan di atas, maka dapat disimpulkan beberapa point terkait bentuk partisipasi politik pemilih pemula yang ada di kecamatan Pontianak Barat pada pilpres 2014 sebagai berikut ; (1) Realitas partisipasi politik bagi pemilih pemula di Kecamatan Pontianak Barat begitu antusias menyambut datangnya pesta demokrasi tersebut. Hal tersebut ditunjukan oleh pemilih pemula dikecamatan Pontianak barat dengan ikut berpartisipasi mensukseskan pemilu pilpres 2014; (2) Program Kerja dalam bentuk partisipasi pemilih pemula di kecamatan Pontianak barat dalam pilpres 2014 adalah pemberian suara, kampanye, dan berbicara mengenai politik, (3) Faktor pendorong terjadinya politik pemilih pemula di kecamatan Pontianak barat dalam pilpres 2014 adalah Pertama kepedulian terhadap nasib bangsa, hal ini dikarenakan pemilih pemula di kecamatan pontianak barat ini menggantungkan harapannya kepada calon presiden tertentu supaya dapat berubah keadaan bangsa menjadi lebih baik lagi. Kedua kesadaran politik untuk berpartisipasi, ini merupakan hal positif yang ditunjukan oleh pemilih pemula di kecamatan Pontianak barat karena mereka sadar akan pentingnya partisipasi dari masyarakat khususnya pemilih pemula dalam mensukseskan pesta demokrasi tersebut. Ketiga rasa ingin tahu, remaja yang berstatus sebagai pemilih pemula pada kesempatan 
pilpres 2014 ini merupakan pengalaman pertama mereka mengikuti pesta demokrasi setelah sebelumnya saat pilres 2009 kemarin mereka hanya menjadi penonton saja, maka dari itu mereka begitu antusias untuk ikut andil dalam pilpres 2014. Keempat figure seorang pemimpin, pemilih pemula di kecamatan Pontianak barat dalam memilih calon presiden juga memperhatikan figure dari kandidat calon presiden. Kelima praktek politik uang, hal ini sangat disayangkan akan tetapi politik uang ternyata masih menjadi daya tarik bagi pemilih pemula untuk menentukan sikap politiknya; (5) Sikap politik pemilih pemula dalam melakukan partisispasi dilatarbelakangi oleh keadaan social si pemilih pemula . artinya faktor pendidikan, keadaan ekonomi, dan keaktifan pemilih pemula dalam beroragnisasi mempunyai pengaruh dominan yang secara tidak langsung dalam menentukan sikap politiknya.

Berdasarkan kesimpulan-kesimpulan yang telah dipaparkan diatas maka saran dari peneliti sebagai berikut; (1) Walaupun minim pengalaman, pemilih pemula seharusnya tidak boleh terpengaruh dari luar. Sebagai generasi penereus, harus mengedepankan idealisme. Jangan sampai sikap politik kita dipengaruhi dari luar terutama dengan adanya praktek politik uang; (2) Pemerintah seharunya memberikan pendidikan politik terhadap generasi muda, terutama pemilih pemula. Hal ini dimaksudkan untuk menambah pengetahuan politik pemilih pemula guna membentengi pemilih pemula supaya tidak terpengaruh dari perbuatan curang, seperti praktek politik uang dalam menentukan sikap politiknya.

\section{DAFTAR PUSTAKA}

Asshiddiqie, (2009). Pengantar Ilmu Hukum Tata Negara. Jakarta: Raja GrafindoPersada Jakarta

Cholisin (2012),Dasar-Dasar Ilmu Politik. Yogyakarta: Ombak.

Gatara, (2008). Ilmu Politik. Bandung:PustakaSetia

Moleong. 2011. Metodelogi Penelitian Kualitatif. PT Remaja Rosdakarya Offset. Bandung

Peraturan KPU Nomor 12 tahun 2012. Tentang Penyelenggaraan Pemilihan Umum. Bandung; Citra Umbara 
Siswo, (2014) tentang Upaya Mengatasi Hambatan untuk Menumbuhkan Partisipasi Politik

Sugiyono (2012), Metodelogi Penelitian Pendidikan (Pendekatan Kuantitatif, Kualitatif dan $R \& D$. Bandung: Alfabeta

Sumber: KPU Kota Pontianak Tahun 2017

Undang-Undang Republik Indonesia Nomor 15 tahun 2011 tentang Penyelenggaraan Pemilihan Umum

Undang-Undang Republik Indonesia Nomor 2 tahun 2008 tentang Partai Politik

Undang-Undang Dasar Republik Indonesia tahun 1945

Undang-Undang Republik Indonesia Nomor 3 tahun 1999 Tentang Pemilihan Umum dan Pasal 2 Keputusan Presiden Nomor 16 Tahun 1999

Undang-Undang Republik Indonesia Nomor 8 Tahun 2012 tentang Pemilihan Umum Anggota DPR, DPD, dan DPRD

Winaputra, S. udin (2012). Pendidikan Kewarganegaraan dalam perspektif Pendidikan Untuk Mencerdaskan Kehidupan Bangsa (Gagasan, Instrumentasi, dan Praksis). Bandung: Widya Aksara Press

Zuldafrial,dkk(2012) Penelitian Kualitatif. Surakarta: Yuma Pustaka

\section{Sumber Internet :}

(http://zakkazanumahsa.blogspot.com/2015/03/cara-meningkatkan-partisipasipolitik.html?m=1. (online). (diakses, Sabtu 22 Januari 2017)

(https://nasriaika1125.wordpress.com/2013/06/18/pemilih-pemula/.(Online). $\underline{\text { (diakses, Sabtu } 11 \text { Maret 2017) }}$

(http://setyowati.blog.uns.ac.id/2016/05/01/civic-educatin-dan-citizenshipeducation/(Online). (diakses, Rabu 28 Maret 2017)

https://www.google.co.id/\#q=jurnal+penelitian+ex+post+facto+pdf+tentang+kpu $\underline{\text { (diakses. Senin } 24 \text { Juli 2017) }}$ 